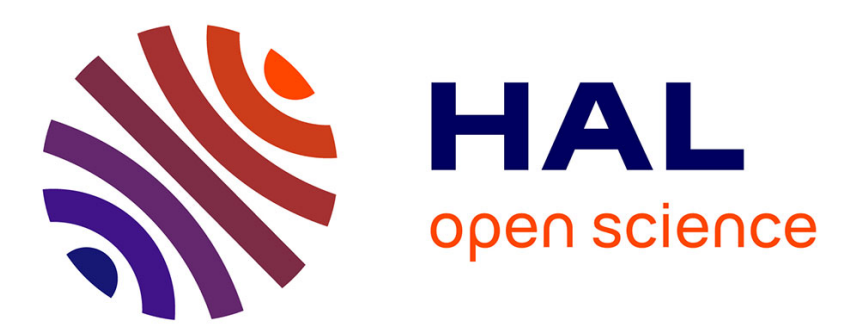

\title{
EXAFS Study of Nanocrystalline Solid Solutions Synthesized in the ZrO2-Ga2O3, System \\ P. Barret, P. Berthet
}

\section{To cite this version:}

P. Barret, P. Berthet. EXAFS Study of Nanocrystalline Solid Solutions Synthesized in the ZrO2-Ga2O3, System. Journal de Physique IV Proceedings, 1997, 7 (C2), pp.C2-1141-C2-1142. 10.1051/jp4:19972163 . jpa-00255227

\section{HAL Id: jpa-00255227 https://hal.science/jpa-00255227}

Submitted on 1 Jan 1997

HAL is a multi-disciplinary open access archive for the deposit and dissemination of scientific research documents, whether they are published or not. The documents may come from teaching and research institutions in France or abroad, or from public or private research centers.
L'archive ouverte pluridisciplinaire HAL, est destinée au dépôt et à la diffusion de documents scientifiques de niveau recherche, publiés ou non, émanant des établissements d'enseignement et de recherche français ou étrangers, des laboratoires publics ou privés. 


\title{
EXAFS Study of Nanocrystalline Solid Solutions Synthesized in the $\mathrm{ZrO}_{2}-\mathrm{Ga}_{2} \mathrm{O}_{3}$ System
}

\author{
P. Barret and P. Berthet
}

Laboratoire de Chimie des Solides, URA 446 du CNRS, Bât. 414, Université Paris-Sud, 91405 Orsay cedex, France

\begin{abstract}
The local structure of $\left(\mathrm{ZrO}_{2}\right)_{1-x}\left(\mathrm{Ga}_{2} \mathrm{O}_{3}\right)_{\times / 2}$ metastable solid solutions ( $\left.\mathrm{x} \leq 0.5\right)$ was investigated by EXAFS. These solid solutions crystallize in fluorite-like structures and are nanocrystalline. From the $\mathrm{Ga} \mathrm{K}$-edge spectra, the gallium atoms are found in an average fivefold coordination $\left(\mathrm{d}_{\mathrm{G}-0}=1.89 \AA\right.$ ). No signal corresponding to a second coordination shell is observed on the radial distribution functions. From the $\mathrm{Zr} \mathrm{K}$-edge spectra, a splitting of the $\mathrm{Zr}-\mathrm{O}$ distances is evidenced. For the lowest gallium content $(x \leq 0.14)$ the zirconium environment is of tetragonal type (4+4), whereas for the higher gallium content (cubic solid solutions) it is more or less similar to that found in monoclinic zirconia $(3+4)$. The signal associated with the second shell decreases with increasing gallium content. These results indicate an important displacement of the gallium atoms in relation to their ideal position in a fluorite structure, which leads to a strong relaxation of the cation network.
\end{abstract}

\section{INTRODUCTION}

The cubic modification of $\mathrm{ZrO}_{2}$, can be stabilized by the addition of lower valence oxides. $\mathrm{Y}_{2} \mathrm{O}_{3}$ is often used for this purpose and $\mathrm{ZrO}_{2}-\mathrm{Y}_{2} \mathrm{O}_{3}$ solid solutions have already been investigated by EXAFS [1-2]. Some unusual solid solutions of $\mathrm{ZrO}_{2}$ and other oxides as $\mathrm{Fe}_{2} \mathrm{O}_{3}$ or $\mathrm{Al}_{2} \mathrm{O}_{3}$ can also be synthesized [2-5].These solid solutions are metastable and nanocrystalline. Similar metastable solid solutions may be synthesized in the $\mathrm{ZrO}_{2}-\mathrm{Ga}_{2} \mathrm{O}_{3}$ system [6]; this paper reports the investigation of their local structure by EXAFS.

As showed by X-ray diffraction (XRD), these solid solutions crystallize in fluorite-like tetragonal $(x \leq 0.1)$ or cubic structures and are nanocrystalline (table I). However, the broadening of the diffraction lines due to the small size of the particules limits the structural information which can be obtained by XRD. Conversely, EXAFS which does not require long range order can provide a convenient description of the local structure.

\section{DATA ANALYSIS}

EXAFS spectra were recorded at the zirconium and gallium K-edges on the EXAFS I beamline at LURE-DCI (ORSAY). Energy selection was accomplished using a channel cut $\mathrm{Si}$ (331) monochromator. Fig. 1 (a) and (b) show the radial distribution functions (RDF) obtained by Fourier transform of $\mathrm{k}^{3} \chi(\mathrm{k})$ at the $\mathrm{Zr}$ and $\mathrm{Ga} \mathrm{K}$-edge for various gallium content. The first peak on the RDF correspond to nearest cation-oxygen shell and the second one to the nearest cation-cation shell. In order to determine the structural parameters of the partial EXAFS contributions, backscattering amplitudes and phase shifts were extracted from model compounds. $\mathrm{BaZrO}_{3}$ was used for the $\mathrm{Zr}-\mathrm{O}$ shell $\left(6\right.$ oxygens at $2.09 \AA, \sigma=0.05 \AA$ ) and $\mathrm{GaAsO}_{4}$
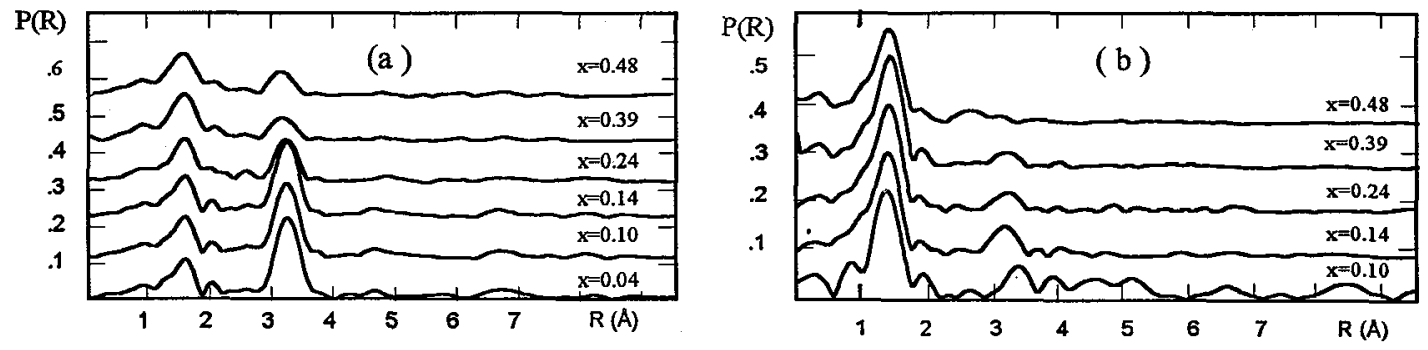

Figure. 1: $\mathrm{RDF}$ of $\left(\mathrm{ZrO}_{2}\right)_{1-\mathrm{x}}\left(\mathrm{GaO}_{15}\right)_{\mathrm{x}}$ solid solutions annealed at $775^{\circ} \mathrm{C}$ (a) $\mathrm{Zr} \mathrm{K}$-edge and (b) $\mathrm{Ga} \mathrm{K}$-edge. 
quartz for the Ga-O shell ( 4 oxygens at $1.825 \AA, \sigma=0.05 \AA$ ). For the second shell observed at the $\mathrm{Zr} \mathrm{K}$-edge, a metastable cubic solid solution $\left(\mathrm{ZrO}_{2}\right)_{0.96}(\mathrm{MgO})_{0.04}$ was used ( 11.5 zirconiums at $\left.3.61 \AA, \sigma=0.07 \AA\right)$.

\section{RESULTS AND DISCUSSION}

\subsection{Oxygen shell}

At the $\mathrm{Zr}$ K-edge, convenient fits of the oxygen contribution were obtained with a two subshell model and a normalization factor of 0.9 . For $x \leq 0.14$, the best fits were obtained with the same number of oxygens in the two subshells. This environment of the zirconium atoms indicates a local order compatible with a tetragonal structure. Such structure is clearly evidenced by XRD for the lowest gallium content, but the tetragonal distortion seems to be too weak to be evidenced by XRD for the two other samples. The difference between the Debye Waller factors of the two subshells could be due to anisotropic thermal motions of the oxygen and zirconium atoms. For $x>0.14$ zirconium is found in a sevenfold coordination, like in monoclinic zirconia. The two subshells, containing 3 and 4 atoms respectively, are similar to those found by neutron diffraction in a cubic yttria stabilized zirconia [7]. For the highest gallium contents, the increase of the number of vacancies leads to an important modification of the zirconium environment.

At the $\mathrm{Ga} \mathrm{K}$-edge, the coordination numbers and the $\mathrm{Ga}-\mathrm{O}$ distances are typical of a fivefold coordination. Therefore, the symmetry of the gallium sites is quite different from that of the zirconium sites.

Table I : EXAFS results for $\mathrm{ZrO}_{2}-\mathrm{GaO}_{1.5}$ solid solutions with various gallium content $\quad$ "Fixed values

\begin{tabular}{|c|c|c|c|c|c|c|c|c|c|c|}
\hline \multirow{2}{*}{$\begin{array}{c}\mathrm{GaO}_{1.5} \text { content } \\
(\mathrm{mol} \%)\end{array}$} & \multirow[t]{2}{*}{ Bonding } & \multicolumn{4}{|c|}{ Zr K-edge } & \multicolumn{4}{|c|}{ Ga K-edge } & \multirow{2}{*}{$\begin{array}{c}\text { Lattice } \\
\text { parameter }(\AA)\end{array}$} \\
\hline & & $\Delta \mathbf{k}\left(\AA^{-1}\right)$ & $\mathbf{N}$ & $\mathbf{R}(\AA)$ & $\sigma(\AA)$ & $\Delta \mathrm{k}\left(\AA^{-1}\right)$ & $\mathbf{N}$ & $\mathrm{R}(\AA)$ & $\sigma(\AA)$ & \\
\hline \multirow[t]{3}{*}{4} & cation-oxygen & $2.8-13.6$ & $4.00^{H}$ & 2.09 & 0.072 & - & - & - & - & \\
\hline & & & $4.00^{\#}$ & 2.31 & 0.115 & & & & & $\mathrm{a}=5.08$ \\
\hline & cation-cation & $6-13.9$ & 9.0 & 3.61 & 0.048 & & & & & $c=5.16$ \\
\hline \multirow[t]{3}{*}{10} & cation-oxygen & $2.9-13.8$ & $4.00^{A}$ & 2.09 & 0.075 & $2.5-10.3$ & 5.2 & 1.88 & 0.091 & $a=5.09$ \\
\hline & & & $4.00^{\#}$ & 2.30 & 0.123 & & & & & \\
\hline & cation-cation & $6-13.9$ & 9.0 & 3.59 & 0.054 & & & & & \\
\hline \multirow[t]{3}{*}{14} & cation-oxygen & $2.9-13.5$ & $4.00^{\#}$ & 2.09 & 0.077 & 2.4-12.7 & 5.1 & 1.89 & 0.091 & $a=5.08$ \\
\hline & & & $4.00^{H}$ & 2.29 & 0.122 & & & & & \\
\hline & cation-cation & $6-13.9$ & 9.0 & 3.59 & 0.053 & & & & & \\
\hline \multirow[t]{3}{*}{24} & cation-oxygen & $2.8-13.3$ & $3.00^{\#}$ & 2.09 & 0.065 & $2.4-13.2$ & 5.2 & 1.89 & 0.095 & $a=5.05$ \\
\hline & & & $4.00^{\#}$ & 2.24 & 0.119 & & & & & \\
\hline & cation-cation & $6-13.1$ & 6.5 & 3.57 & 0.068 & & & & & \\
\hline \multirow[t]{3}{*}{39} & cation-oxygen & $2.8-13.3$ & $3.00^{\#}$ & 2.08 & 0.061 & $2.4-13.1$ & 5.0 & 1.89 & 0.091 & $a=5.00$ \\
\hline & & & $4.00^{\#}$ & 2.21 & 0.120 & & & & & \\
\hline & cation-cation & $6-13.2$ & 5.0 & 3.54 & 0.079 & & & & & \\
\hline \multirow[t]{3}{*}{48} & cation-oxygen & $2.9-13.3$ & $3.00^{\#}$ & 2.09 & 0.066 & $2.4-13.0$ & 5.1 & 1.89 & 0.104 & $a=4.97$ \\
\hline & & & $4.00^{\# \prime}$ & 2.22 & 0.118 & & & & & \\
\hline & cation-cation & $6-13.2$ & 5.2 & 3.54 & 0.082 & & & & & \\
\hline
\end{tabular}

\subsection{Cation shell}

On the RDFs obtained at the Ga K-edge, the amplitude of the second peak is very weak. This indicates an important displacements of the gallium atoms in relation to their ideal position in a fluorite structure. Therefore, the $\mathrm{Ga}-\mathrm{Zr}$ distances are widely distributed and the second peak observed in the RDFs at the $\mathrm{Zr} \mathrm{K}$-edge are only due to scattering by zirconium atoms. For $\mathbf{a}\left(\mathrm{ZrO}_{2}\right)_{1-x}\left(\mathrm{GaO}_{1.5}\right)_{x}$ solid solution, the number of $\mathrm{Zr}$ atoms in the second coordination shell around zirconium is given by $\mathrm{N}_{\mathrm{Z}}=12^{*}(1-\mathrm{x})$. Even taking account uncertainties close to $20 \%$, the experimental values are always lower than the calculated ones, which suggests some distortions of the cation network. However, the $\mathrm{Zr}-\mathrm{Zr}$ distances are in good agreement with those deduced from the lattice parameters $(a / \sqrt{ } 2$ for the cubic structure).

\section{References}

[1] Tuilier M.H., Dexpert-Ghys J., Dexpert H. and Lagarde P., J. Solid State Chem., 69 (1987) 153.

[2] Li P., Chen I-W. and Penner-Hahn J.E., Phys. Rev. B, 48 (1993) 10063.

[3] Stőcker H.J., Thèse d'état, Ann. Chim. 5 (1960) 349.

[4] Davidson S., Kershaw R., Dwight K. and Wold A., J. Solid. State Chem. 73 (1988) 47.

[5] Berthet P., Berthon J. and Revcolevschi A., Physica B158 (1989) 506-507.

[6] Barret P. and Berthet P., J. Phys. III France (to be published).

[7] Steele D. and Fender B.E., J. Phys. C7 (1974) 1-1 1. 